\title{
The Level of Reading and Writing Proficiency among B40 Students from the Malay Language Teachers' Perspective
}

\author{
Zamri Mahamod ${ }^{1, *}$, Rohaida Mazlan², Norziah Amin, Mohd Zaki Abd. Rahman ${ }^{3}$ \\ ${ }^{1}$ Faculty of Education, Universiti Kebangsaan Malaysia, Bangi, Selangor, Malaysia \\ ${ }^{2}$ Sungai Ramai Secondary School, Kajang, Selangor, Malaysia \\ ${ }^{3}$ Hulu Langat District Education Office, Kajang, Selangor, Malaysia
}

Received January 6, 2021; Revised February 22, 2021; Accepted March 12, 2021

\begin{abstract}
Cite This Paper in the following Citation Styles
(a): [1] Zamri Mahamod, Rohaida Mazlan, Norziah Amin, Mohd Zaki Abd. Rahman, "The Level of Reading and Writing Proficiency among B40 Students from the Malay Language Teachers' Perspective," Universal Journal of Educational Research, Vol. 9, No. 3, pp. 638 - 649, 2021. DOI: 10.13189/ujer.2021.090323.
\end{abstract}

(b): Zamri Mahamod, Rohaida Mazlan, Norziah Amin, Mohd Zaki Abd. Rahman (2021). The Level of Reading and Writing Proficiency among B40 Students from the Malay Language Teachers' Perspective. Universal Journal of Educational Research, 9(3), 638 - 649. DOI: 10.13189/ujer.2021.090323.

Copyright $\bigcirc 2021$ by authors, all rights reserved. Authors agree that this article remains permanently open access under the terms of the Creative Commons Attribution License 4.0 International License

Abstract This qualitative study examined the level of
proficiency of reading and writing skills among students
from the B40 families from the Malay Language teachers'
perspective. A sum of four Malay Language teachers who
teach B40 students were interviewed. It concerned two
Malay Language teachers teaching in Secondary School A
(SSA) and two Malay Language teachers teaching in
Secondary School B (SSB). The participants of Malay
Language teachers comprised three females and one male
teacher. All Malay Language teachers are qualified
teachers, having teaching experience between 11 to 25
years. Structured interviews were used as research
instruments. The researchers analysed interview data
narratively, and the themes derived were based on
interview questions. The outcomes confirmed that all B40
Chinese, Indians and Malays students had minimal reading
and writing level. B40 Chinese students had the weakest
reading and writing skills. The four Malay Language
teachers established that the B40 Chinese students had the
weakest reading and writing skills, followed by B40
Indians and B40 Malay students. The Malay Language
teachers affirmed that attitudinal factors were the principal
grounds B40 students could not read, particularly B40
Chinese students. Essentially, the researchers identified
attitude factors and parent support as drivers to the failure
of B40 students to master reading and writing skills proficiently.

Keywords Reading Proficiency, Writing Proficiency, B40 Students, Malay Language Teachers, Secondary School

\section{Introduction}

The predicament of reading and writing is still unsolved. To this day, there are primary and secondary school students who cannot read and write. Annually, in National Secondary Schools (NSS), various rehabilitation classes are established to accommodate students who are still illiterate or less competent in reading and writing. The incapacity to read and write in Malay still exists in the education practice, although the number of illiterate people decreases.

National Secondary School (NSS) is a secondary school under the Malaysian Ministry of Education (MoE) governance. These secondary schools accept various students. It includes students with weak academic achievement and needs corrective classes to help them succeed in teachings, such as reading and writing. Most students who encounter reading and writing difficulties 
come from low-income families (B40). According to the [34] in CompareHero.my, the average household income below Ringgit Malaysia (RM) 3166 is classified as low-income people (B40). In this research, almost all students who struggle with reading and writing the Malay Language came from low-income families or B40.

Students' failure to master reading and writing skills proficiently needs to be addressed promptly. It determines the performance of students in learning the Malay Language. A study attended by [11], for example, stated that the Chinese were weak in reading and writing skills. Similarly, a study administered by [18] discovered that Indian students experienced trouble and confusion to learn the Malay Language.

Hence, are the failures and weaknesses of Malay students and non-Malays, mostly Chinese and Indian students, affected by family background factors? Do low-income parents influence students' reading ability and capacity to read and write? Does the background of students coming from the B40 families discourage them from being fluent and competent in reading and writing in the Malay language?

Thus, this research intended to assess students' reading and writing proficiency from B40 families from Malay Language teachers' perspective. Malay Language teachers are teachers who teach the B40 students.

\section{Statement of Problem}

The subject of families earning below Malaysia Ringgit: RM3166.00 is an issue that is the focus of the current government. Almost $40 \%$ of the Malaysian population consists of households with a monthly income below the poverty line income [13]. Since the B40 group/family is usually low-income families, this determinant also hurts the welfare of the B40 families, particularly to their children, in terms of housing, food, clothing, and education.

Most of these B40 families/parents are uneducated/ schooled until secondary school only. Their daily lives are occupied, making a living that some neglect their children's progress in terms of education. They / their B40 families send their children to the school and expect teachers to educate their children. A study attended by [19] and [22] determined that the B40 group/family's low socio-economic factors caused the B40 group/ family not to afford essential facilities for their children such as life insurance/ education and high-quality teaching. Thus, it directly impacted children's learning, such as being incompetent during lessons, weak / failed to read and write competently.

Economic quandaries between classified B40 groups/ families hinder a sound education for their children, such as tuition and study aids. The parents' income is mostly to maintain the family and complete payment of various bills for survival. Hence, B40 parents ignore their children, including education interests. B40 parents concentrate on the economic features of the educational factor of their children. A study by [33] decided that most B40 families prioritised financial aspects over others, such as education and welfare.

Hence, they neglected children at home. Parents do not care whether their children can read or write or not. A study conducted by [9] among Bidayuh ethnic students affirmed that almost $75 \%$ of Bidayuh students still have poor reading skills. Since most Bidayuh students come from B40 families, reading problems are a significant dilemma among them. According to [24] and [19], most students who had reading problems would face academic issues, too, as low-income families lack awareness of the importance of reading.

The same situation applies to aspects of writing skills. Students from B40 families also generally have problems with writing skills. Investigations conducted by [2], [3] and [26] showed that primary school students arestill incapable of mastering excellent writing skills. Most of the students considered were rural students and from low and middle-income families. Because of achieving poor writing skills and a moderate level, it immediately affected students' achievement in Malay Language learning. According to [4], rural students' writing problems greatly influenced student achievement in Malay Language writing skills.

The preceding scholars never specifically studied the subject of reading and writing skills of students of the B40 group/family in Malay Language education. Most topics on the level of mastery of reading and writing skills and students' problems were general. Although the study respondents arereferred to primary school students, rural students, and students' backgrounds, they never examined the B40 families.

Therefore, this research explored and analysed the level of reading and writing proficiency of B40 students from the Malay Language teachers' perspective.

\section{B40 Student}

The school education domain in Malaysia develops progressively. Numerous educational transformations were introduced and executed by the MoE (Malaysian Ministry of Education) in ensuring that every Malaysian acquires a quality education. The dedication of the Malaysian Education Development Plan 2013-2025 (PPPM 2013-2025) [14] confirms the MOE's engagement and gravity in augmenting education quality in all educational aspects. To ensure that they implement all plans and shifts projected in PPPM 2013-2025 thoroughly, they then incorporate the components of access, quality, equity, and educational efficiency in the policy in the success of PPPM 2013-2025. 
Educational access refers to the equality of educational access that all Malaysians must realise, including students from B40 families. According to [32], equality of educational access could guarantee that the PPPM 2013-2025 constituted can be fully achieved by 2025 . In the context of this study, equality of educational access must be delivered and experienced by students of the B40 families. They are entitled to a top-notch education, even though some of them cannot read or write.

The corresponding situation applies to the equity and quality of education. It is about whether the students from the B40 families manage to get access, quality and equity of education? Following [19], most primary and secondary school students belong to the B40 group. Parents can be characterised as low-income groups and classified as needy. Most of them live in rural areas. They do not obtain a quality education, and there is no attempt to guarantee that all these B40 students do not experience academic dropout. Many conditions cause B40 students to continue to experience such a scenario. The most critical factor is parents' financial circumstance leading to B40 parents' failure to provide educational facilities for their children, such as learning materials and tuition classes.

A study administered by [15] on B40 group students' education discovered that almost two-thirds of B40 students had low academic achievement. Low-achieving B40 students in the Malay Language was extremely influenced by their performance, attitudes, motivation and behaviour. According to [25], low-achieving students often refer to students who do not attempt to improve academic achievement, do not concentrate in the classroom, do not show interest in the learning process, disregard homework, do not listen to teachers' advise, disagree with the teacher and are not involved in the learning process in the classroom. They also have no learning culture, and most of them live in rural areas and come from low-income families (B40).

Research directed by [15] also found that school administrators and teachers are the central factors influencing students' achievement, including B40 students. [17] affirmed that teachers are the principal factor determining students' academic achievement in Lower Secondary Assessment. The study conducted in Sabah too decided that parents' socio-economic status, educational level of parents and friends contributed to students' academic achievement. It implied that if school administrators and teachers could improve the quality of education, learning facilities and access to academic education, it would promote students' accomplishment. Hence, schools' quality of education can significantly affect students' academic achievement, including among B40 students.

In essence, students of B40 families necessitate many parties to thrive in their studies. Regardless of race, gender and statistical boundaries, the educational problems and low academic achievement of B40 students need to be addressed promptly. B40 students require class teachers, subject teachers, parents and peers to succeed in lessons. Accordingly, the school's quality, equity, access, and educational efficiency needs to be advanced so that all students, including low-achieving and B40 students, can achieve and obtain it ultimately, just as obtained by M40, high-income, and high-achieving students.

\section{Methodology}

This study's design was a case study, a single case multiple site studies [27]. A single case study referred to students' being incompetent in reading and writing the Malay Language by the students of the B40 families. These students were Form 1 students identified in two National Secondary Schools (NSS) in the Hulu Langat district, Selangor, Malaysia. The multi-place study referred to the location of the school that was the place of study data collection. Thus, researchers identified two SMK B40 families who could not read and write in the Malay Language. The researchers recognised these two schools with School Improvement Specialist Coaching (SISC+) from the Hulu Langat District Education Office (PPD Hulu Langat), Kajang, Selangor, Malaysia.

This research employed a case study design using a qualitative approach. Case studies were conducted in various places (two NSS locations) to determine the reasons and problems that caused students from B40 families unable to read and write. In this study, the cases studied were problems reading and writing Malay Language. Various secondary schools in the district identified many different races from B40 families who could not read and write in the Malay Language.

Participants in the study were a case study of Malay Language teachers who teach B40 students with low reading and writing proficiency. These four teachers teach the Malay Language of Form 1 and teach students who had difficulty reading and writing as the study participants. Participants from NSS-A were two, and both were female teachers. Participants from NSS-B were two, with one male and one female teacher. All Malay Language teachers have experienced teaching between 11 and 25 years. Table 1 shows the number of participants in this study.

Table 1. Number of Malay Language teachers as a study participant

\begin{tabular}{|c|c|c|c|}
\hline \multirow{2}{*}{$\begin{array}{c}\text { School } \\
\text { Category }\end{array}$} & \multicolumn{2}{|c|}{ Teacher Gender } & \multirow{2}{*}{$\begin{array}{c}\text { Total } \\
\text { Teacher }\end{array}$} \\
\cline { 2 - 3 } & Male & Female & 2 \\
\hline NSS-A & - & 2 & 2 \\
\hline NSS-B & 1 & 1 & 4 \\
\hline Total & 1 & 3 & \\
\hline
\end{tabular}

A case study of these various places used interview data. The researcher used a structured interview to interview Malay Language teachers who teach students of the B40 family. Data analysis was the process of managing, 
structuring and giving meaning to the data collected by [12]. Therefore, the data obtained could be maintained, stored, used or even set aside if it did not meet the question's requirements. The data analysis process took place continuously for each data collection technique used. This continuous data analysis aimed to launch and facilitate the data collection process. Structurally managed data conditions helped the process of analysing real data.

The data analysis procedure involved several stages. According to [16], the phases consisted of managing data, forming categories, themes and forms, encoding data, validating and subsequently writing reports. [9] recommended several steps, namely analysing data habits by repeatedly reading, collecting data, identifying categories and theme formation, implementing the coding process, revising code, types, themes or sub-themes, validating data by peer review, making summary form theme tree, interpreting data and writing reports. In this research, the researchers completed the data analysis procedure manually.

\section{Research Findings}

\section{Malay Language Teachers Demography}

This study chose four Malay Language teachers who teach students B40 who could read and write as the participants. Two Malay Language teaching in NSS-A (city school). The teacher was Ms Kamaliza (not real name) and coded: PKG01 and teacher Ms Noraini (not real name) and coded: PKG02. Then, the research elected two Malay Language teaching in NSS-B (rural school). The first teacher was Ms Wahida (not real name) and coded: PKG03. The second teacher was Mr Ridzuan (not real name) and coded PKG04. All Malay Language teachers were selected based on:

1. They teach B40 students who do not know how to read and write.

2. They volunteer to be study participants and interviewed.

\section{Problems Faced by B40 Students in Reading and Writing Skills}

This section discusses the question: What are the problems faced by the students in the B40 families in reading and writing skills from the perspective of Malay Language teachers? A total of four Malay Language teachers participated in the study. These four teachers teach at two NSS, which were the study locations. A total of two teachers was from NSS-A, a school categorised as an urban school. A total of two teachers was from NSS-B, a school classified as a rural school. From NSS-A, the teachers were coded as Teacher Study Participants (PKG) 01 or PKG01 and PKG02. From NSS-B, the teachers were coded as
PKG03 and PKG04. From the interview of all PKG, the researchers formed four themes based on interview questions posed, namely: (i) teaching experience, (ii) creating an environment of Malay Language, (iii) the teacher as the leader continued, and (iv) promoting the use of Malay Language in teaching and learning. These four themes were compared to PKG's problems throughout the teaching of B40 students, either related to reading or writing skills.

\section{Malay Language Teachers Experience Teaching B40 Students}

All four PKG agreed that during the teaching period of these B40 students, all of them did not master reading and writing skills, especially Chinese students. All PKG acknowledged that these B40 students did not master reading and writing skills through their teaching experience. They did not know how to read and write as Malay students, Chinese and Indian students followed based on the arrangement. If they could read or write, most did not know what to read and write. Attitude determinants such as not listening to the teacher and uninterested in reading or writing become factors not to read and write efficiently among these B40 students. It is evident from the interviews conducted on every PKG. For example:

Can you please tell me a little bit about the teacher's experience while teaching students who have reading and writing problems? Students mostly face difficulties in writing skills than reading and speaking skills. In the class, I teach 32 students who are Chinese and Indians. Some students can read but do not understand what is read, and some can write but do not understand anything written. They copy (what is written). Even though it only concerns copying, they still make many language mistakes. (Interview/PKG01)

Can you please describe the experience of teaching students from these B40 families who cannot read and write? I teach Form 1 students. I just teach these classes after the Movement Control Order (PKP). I teach this class for three months. They face reading problems. Most of these issues are suffered by especially Chinese students, then the Indian students. The Chinese students study in a transition class for six years in primary school (Chinese national type school), they cannot master reading skills. (Interview/PKG03)

PKG also noted that nearly all students who did not know how to read and write concerned with various races, whether Malay, Chinese or Indian. However, the teachers highlighted B40 Chinese students, as most of them could not read or write, followed by B40 Indian students. All PKGs also agreed that the B40 students they teach came from low-income families. It is evident in PKG01 and 
PKG04 when interviewed.

Throughout teaching Malay Language subjects, have you ever met B40 students who have reading and writing problems? Most of the students with reading and writing problems are from the B40 family compared to other status families. Most of these students come from the Transition class, which explains why very few Malay students face this problem. (Interview/PKG01)

Based on the experience of B40 students who face this problem. What is the situation of students in this school who have reading and writing problems? Can you please explain? In this school, I recognise the weakness in B40 students in terms of speech, especially non-Malay students. They communicate in mixed and informal languages. Hence, when they answer exam questions, they cannot distinguish between colloquial and formal Malay Language. That is how I know that the students are Malays. For students of other races, their communication at home will affect it. The base factor of Chinese and Indian school students also contributes to this problem. But for Malay students, I notice they cannot distinguish the use of appropriate language when using formal or informal situations. (Interview/PKG04)

In terms of B40 students, all four PKG stated that most B40 Chinese students could not read or write. B40 Indians and students Malays followed this. B40 Chinese students cannot read and write, do not listen to the teacher, do not focus on learning, disrespect the teacher, annoy friends, and be mischievous in the classroom. Thus, there were many reasons why these multi-racial B40 students could not read and write. It is apparent from PKG02 and PKG03 when interviewed about B40 students:

During your 20 years of teaching the Malay Language for Form 1, which one of the skills, hearing speech, reading and writing, students find most challenging to master? Writing skills are the most difficult skills for students to master, especially for Chinese students. Malay students do not face problems in my class. There is a problem with Malay writing. He was a student from a transition class last year, and he also attended a Chinese national type school while he was in primary school. However, this student can still read regularly, but he does not understand what he is reading. (Interview/PKG02)

What is the root of the problem that troubled Chinese students to master reading the Malay Language? There are many causes. One of the factors is the attitude of Chinese students who do not listen to the teacher. It concerns their other disciplinary problems. They do not respect the teacher who teaches them, do not listen to the teacher. They are also less focused on lessons in the classroom. They are bored with learning the same topic in high school but still do not master reading skills. When the same thing repeats, they do not understand. Because they are not focused, when asked to make simple sentences, they cannot form them. In particular, some Chinese students can spell and pronounce but do not know what the thing is. They do not know what it means. For example, the word 'cup', they understand what a cup is. But when it comes to 'kettle', they do not know what a kettle is. The teacher has to show a picture to help the students understand what a kettle is. Also, Form 1 Malay Language textbook is not suitable. This textbook is a high level of transition class students. It is inappropriate. (Interview/PKG03).

Based on these teaching experience factors, one can conclude that all PKG agreed that:

1. Reading and writing problems of B40 students vary by race.

2. B40 Chinese students are more problematic in reading and writing skills than students B40 Indians and Malays.

3. The attitude factor is the main factor that causes reading and writing problem among $\mathrm{B} 40$ students of various races.

\section{Malay Language Teachers Pedagogy in Creating a Language Environment}

The second theme refers to school administrators and teachers' role in creating a Malay Language environment. A total of six questions were asked to PKG about this. This subject aimed to determine whether the Malay Language school environment made by school administrators could help students who could not read and write the language involved in the activities held? Finally, were they interested in learning Malay Language and did it help them master reading and writing skills?

To create an environment of the Malay Language in schools, school administrators held various activities. The four PKG stated that school administrators supported the NILAM activities organised by the Malay Language Committee. In addition to NILAM activities, the school also held special activities that involved reading skills such as having: (i) a Reading Program conducted by the School Resource Center, (ii) 7-Minute Reading Activities and (ii) Language Month. For students who could not read and write, the school would: (i) hand over students who are weak or unable to read and write this to individual teachers for recovery sessions and (ii) take students who could not read to the School Resource Center to draw their engagement in reading. All these statements were mentioned by PKG01, PKG02, PKG03 and PKG04. For example:

Throughout the teacher's teaching at this school, has the school ever created activities or programs to help students with reading and writing problems? The school used to conduct poetry reading, storytelling 
and essay writing competitions for each level. Participation is mandatory for all students based on the subject teacher of the class. (Interview/PKG02)

Do we further question school administrators' role in promoting reading the Malay Language at school? The school plays its role. The committee that comes under the Malay Language organises NILAM activities. When I teach 30 minutes / half an hour, I will take the class of students who do not know how to read this to the Resource Center. They will be asked to read and write down what books they read. Most of them, especially Chinese students, do not write, do not make notes. So, this Chinese student comes to the Resource Center to sit alone. Some of them sleep. Then, how can one expect to be good at reading or writing? The school also holds a 7-Minute Reading activity. Before the Movement Control Order (PKP), there was a School Assembly session. But, after PKP, we have to conduct a 7-Minute Reading activity in class. (Interview/PKG03)

The school also provides various facilities to support teaching and learning the Malay Language effectively in school. All of PKG supported that the school offers many facilities that support teaching and learning the Malay Language. Among them are (i) there is the Internet to support teaching and learning activities, (ii) there is a language laboratory and (iii) there is a language corner. All of these facilities are provided by the school in collaboration with the Committee of Malay Language. Creating a language environment in schools will indirectly boost the interest and motivation of B40 students who do not know how to read and write to participate in the activities implemented. It is evident in PKG01 and PKG03 interviews.

How to easily support learning the Malay Language in school? As a TS25 school, I do not have a problem with teaching sessions because the administrators always help with this aspect. The only problem is the internet issue, as many schools face, which cannot be wholly overcome. (Interview/PKG01).

What about T\&L facilities to support $T \& L$ of the Malay Language? Is it enough? There is a problem. The learning aids to help illiterate students are not enough. Some do not exist at all. There are no up-to-date aids. If there are any reading and writing aids, it is worn material. (Interview/PKG03).

Therefore, a conducive school environment with various language activities also encourages the interest in reading and writing of B40 students. The school teachers, especially Malay Language and Committee Malay Language, can help with the reading and writing of B40 students with assistance and administrative support. Some of the activities that school administration can do are:

1. Providing many teaching aids under the Committee Malay Language.
2. Involving B40 students in each language activity.

3. Placing students who do not know how to read and write in a classroom of no more than 20 people in one class.

4. Buying learning aids in the form of images to attract students not interested in learning the Malay and non-Malay to learn.

5. Creating more language corners in school and the classroom.

6. Improving Internet infrastructure to encourage students B40 to learn the Malay Language through online learning.

\section{Malay Language Teachers as a Continuous Leadership}

The responsibility as a teacher is enormous, and it applies to the Malay Language teachers who participated in this study. As a leader who continues to educate and give their students guidance, all these PKG set an excellent example in teaching these B40 students. Malay Language teachers will continue to demonstrate continued leadership as an educator, especially when teaching students of different B40 races families who still have problems reading and writing. Various ways that PKG can do as a continuous leader in its field, such as:

1. Teaching the standard Malay Language without mixing with the Malay Language.

2. Believing that the problem of illiteracy faced by these B40 students can be solved.

3. Striving to find ways to solve illiteracy by B40 students, such as talking to class teachers and their parents.

To help these B40 students overcome reading and writing problems, PKG01, PKG02 and PKG04 used various methods. However, PKG03 was not sure to support these B40 students with their reading and writing problems. On the other hand, PKG01, PKG02 and PKG04 were confident of helping in ways such as (i) making reading interventions, (ii) not giving many assignments, (iii) motivating, (iv) using reading books and other methods and techniques that PKG using. PKG01 and PKG02 responded:

What is the implementation of interventions for students with reading and writing problems? I conducted an intervention class at noon, met them and guided them individually. Teachers also need to run Drill Techniques for certain aspects of the Malay language. I also asked students to copy the answers to master their writing. (Interview/PKG01).

What are the most effective teaching methods or techniques to help these students with problems as an experienced teacher? The most effective strategy I used while they were in the transition class was reading with the teacher's help repeatedly, i.e. the teacher read the students follow. I also took advantage 
of substitute teacher class time to teach them to read by asking them to read in front of the class. But now, during Form 1 P \& P, I would teach them to read Malay one by one. (Interview/PKG02)

In ensuring that these B40 students quickly master reading and writing skills, all PKG took various approaches. Some of the initiatives are:

1. Talking to the B40 student class teacher.

2. Contacting the parents of B40 students.

3. Talking to the parents of B40 students about their children's education.

Nevertheless, the achievement of B40 students in mastering reading and writing skills does not get full cooperation from the parents of B40 students. Although parents provide cooperation, they help teachers in supporting their children to master reading and writing skills. Among their reasons for disengagement were:

1. There is no time to come to school.

2. They do not work together to help their children read and write.

3. They fully expect teachers to teach their children to master reading and writing skills.

PKG02 and PKG03 expressed the reasons given by these parents during the interview.

What about the involvement of their parents with the activities that the school conducts? Their parents have never attended any school activities such as General meetings, Academic Day or customer meeting days. To me, that is the main problem these students fail to master reading and writing skills. Most of these parents do not care about their children's academic affairs. (I had) experienced a Chinese student, came to school alone, without being accompanied by his mother or other family members, during the first day of school. (Interview/PKG02)

How do the parents of these students respond to the problems their children face at school? It is a bit disappointing. The parents of these B40 students rarely come to school. They completely expect education from the teacher. They do not attend the Parents Teacher Association (PTA) meetings. They accept teachers who reprimand their children, cane their children, punish their children and take disciplinary action against their mischievous children. Parents have no time. They leave it entirely to the teacher to educate their children. If their child does not know how to read or write, they leave it to the teacher to teach them to read and write. (Interview/PKG03).

All efforts made by the Malay Language teachers and schools to help students B40 to read and write will not be successful if the children's parents are not doing their part. Through interviews with PKG, all PKG said 'YES'. Parents should work with teachers and the school to help their children read and write. However, the cooperation of parents, in this case, was unsatisfactory. Most parents of B40 students:

1. Do not provide cooperation for sharing the problems of their children.

2. Do not care about the level of mastery of their children.

3. Do not help children in terms of providing them with learning equipment.

All PKG agreed that the parents of B40 students should help the teacher and the school. Instead, they do not play a proper role in this. It is evident in PKG03's interview:

As a teacher, does the B40 family background influences students with reading and writing problems? I strongly agree. Parents need to play their part. They have to help teachers to help their children read and write. Parents need to assist in this regard. Parents cannot leave all the problems of students who are not good at reading and writing to the teacher. Instead, parents can help teachers and school. The method is to ask the children at home and help them with school work. Parents need to know whether their child can read and write or not. Parents should not expect teachers at school to help their children read. Do parents not play their role? Not all. As I said at an early stage, most of these B40 students' parents are busy making a living. There is no time to engage with their children's lessons. They expect the school to help their children read and write. It especially applies to Chinese students. If their children do not like school, they tell their children to work the way they experience life. But there is no such culture among Malays and Indians. These students continue to study until Form 5. (Interview/PKG03)

Thus, teachers of Malay Language leader continuously help with reading and writing problems B40 students face. Malay Language teachers need to be confident that they can help B40 students to read and write well. Ongoing leadership in the context of teaching and learning for these B40 students is by way of:

1. Teachers use the Malay Language to teach the Malay Language.

2. Teachers Malay language feel unsure B40 may help students to read and write.

3. Talk to class teachers and other subject teachers about B40 students.

4. Inform parents about their child's attitude and educational performance.

5. Not implementing intervention classes for B40 students who have difficulty reading and writing.

6. Agree that the parents' role is vital in helping their child/B40 student read and write.

\section{The Way of Malay Language Teachers Promoting the Use of Language in Teaching and Learning}

PKG Malay used various means and methods to 
encourage B40 students who did not know to read and write. As experienced Malay Language teachers, who teach B40 students who could not read and write, all four PKG always encouraged B40 students to use the Malay Language properly. Among the encouragements used was to:

1. Provide easy reading material to read through the NILAM activities/program.

2. Purchase books and stationery to inspire B40 students to read and write.

3. Encourage B40 students with love / not being offended while teaching.

4. Encourage the non-Malays students to speak the proper Malay Language.

5. Advise B40 students on how to speak the proper Malay Language.

6. Give appreciation and reward to B40 students who have improved in reading and writing skills.

PKG Malay Language used all six encouragements when interviewing PKG03 and PKG04.

In Malay Language class, while the $T \& L$, do teachers encourage students to read the writing in question using the Malay Language? As a Malay Language teacher, I would encourage non-Malays students, Chinese students and Indian students to use the Malay Language. As they speak, I will reprimand the way they speak and correct as much as possible. What is the student response in this case? For the Malay students, they have no problem. They can speak the Malay Language well. As for the Chinese students, both male and female, they find it difficult to speak. But I will force them to speak in the Malay Language. Indian students are supportive. They cooperate. They speak the Malay Language much better than Chinese students. (Interview/PKG03)

During the T\&L, does the teacher encourages students who have problems reading and writing using the Malay Language? We sure do, especially for the Malay Language subject. Teachers will use the Malay Language completely. Students with poor command of the language will communicate in the Malay Language. How does this student respond? As I mentioned at the beginning of our discussion today, some students do not understand the Malay Language, mostly the Chinese and Indians. Malay students have no problem. It is only for some words or phrases, and the teacher has to explain more in-depth. Teachers also have to use simple language for students to understand. Some students will repeatedly ask their friends the meaning of certain words or sentences they do not understand. For example, if for other subjects, such as Science, the teacher has to use the Malay Language for specific terms so that students can understand the meaning of the word. (Interview/PKG04).
Although PKG Malay Language encouraged motivational and rewards such as (i) giving star, (ii) providing food, (iii) giving money, and (iv) congratulating the B40 students' performance in Comprehension and Written Test was still unsatisfactory. Their achievement was very weak, and the marks obtained for Comprehension Test and Written Test were below 20 to 30 marks. B40 Chinese students were not good in Written and Comprehension Tests, and most of them got below ten marks than students B40 Indians and Malays students. It is evident in PKG01 and PKG03 interviews:

How is the achievement of test/assessment marks that have been implemented recently? Students score around 0 to 20 marks in the recent test. All these students do not pass, and they just submit blank papers. The students do not answer but copy the questions. (Interview/PKG01)

What are the test or examination results that these students? Do they all pass? It is hard, sir. Most of them cannot read. They do not know how to read the Malay Language. If one knows how to read, some do not understand what one reads. That is why most tests do not reach the targeted par. It is not easy to achieve 35 per cent passing marks. Especially Chinese students, it does not apply to all. Most of their marks are below ten. Why? Because they do not know how to read and write in the Malay Language. (Interview/PKG03)

To ensure these B40 students can read or write well during teaching and learning, PKG Malay Language used various fun activities and involved all B40 students who could not read and write. Among the activities PKG Malay Language covered in class were:

1. Do group activities. The purpose was for all B40 students to be actively involved in reading and writing skills.

2. Organise simple activities such as filling in the blanks.

3. Ask students to copy and repeat the teacher's answers on the blackboard.

4. Do many exercises.

5. Many use digital or technology applications when teaching.

6. Make storytelling activities, language games, arrange letters cards and use pictures to help B40 students read and write.

7. Use entertaining learning techniques in involving students in every activity carried out.

8. Use the Reading Module and Writing Module to help B40 students read and write well.

The teachers did all these activities, as mentioned in interviews with PKG02 and PKG03. They said:

What kind of training do most of these students prefer? Most of them like the objective activity because they 
do not have to write a lot and just read the questions. If they do not know the answer, they can still mark the answer they like. When it comes to the essay questions and comprehension for students, those who do not know the answer will copy the question or leave it blank. Most of them answer review or summary questions because they can replicate the passage by section and the stimulus material essay. These students will answer by copying the given phrase. (Interview/PKG02)

What activities do you carry out during $T \& L$ that can help students with this reading and writing problem? Lower secondary students like the class I teach like to play in class. It suggests fun learning. They do not like teachers who formally teach. They like teachers who teach while playing. They will love it. They will become active and participate. For example, while I am teaching, I will use storytelling techniques. Storytelling techniques are part of the Fun Learning method. I will relate the story to the student's life in terms of their experience. Also, I use the language game method. For example, I do a letter-stacking activity to build words. I do group activities. Students have fun doing the action of arranging letter cards in groups. Besides, I always use pictures. I take photos related to the students, such as houses, cars, motorcycles, cats, and dogs. Then, I will ask the students to converse based on the picture voluntarily. Many students can do it. Although the language may seem disorganised, contain poorly stated grammatical sentences, students who are Malays, Chinese and Indians who cannot read and write can speak well using simple sentences. But when I asked them to write what is mentioned in the exercise book, they cannot do it. If I force them, I am not sure what they will write. (Interview/PKG03).

Hence, it is evident that the Malay Language teachers who became participants study employed various strategies, approaches, methods and techniques to help the B40 students' master reading and writing skills. Multiple forms of encouragement used by the Malay Language teachers to ensure B40 Malays, Chinese and Indians students can read and write well, such as the following:

1. Encourage students to participate in reading and writing activities.

2. Ensure that student work can be performed by students quickly.

3. Provide reading and writing activities appropriate to the student's level of mastery.

4. Give rewards and appreciation to B40 students through the work that they do.

5. Use various methods, approaches, techniques, and strategies to help B40 students master reading and writing skills.

\section{Discussion}

The research involved four Malay Language teachers who teach B40 students with low competency in reading and writing the Malay language. The most extended teaching experience was PKG03 teaching for 25 years, 23 years teaching by PKG01, 20 years teaching by PKG02, and 11 years teaching by PKG04. Based on the teaching experience, all Malay Language teachers responded that the reading and writing of B40 students were different according to race. B40 Chinese students were more problematic in mastering reading and writing skills, followed by B40 Indians and Malay students.

These findings explained that the reading and writing difficulties of most of the B40 students apply to non-Malay students. Due to the non-Malay students learning Malay Language as a second language (probably the third language), it will be difficult for them to master the Malay Language well. According to [31], the non-Malay students were weak in the Malay Language because they did not consider this a necessary subject to master. Nevertheless, the study by [1] showed the opposite findings. Chinese students could master reading and writing skills if the Malay Language teachers use various teaching methods that interest them in learning the Malay Language. The problem of incompetence to master reading and writing skills for B40 students, especially Chinese students, was caused by their attitude towards learning the Malay Language. The findings showed that the attitude factor was the main determinant that caused reading and writing problems among B40 students of various races. This finding was related to previous studies [1], [11]. [20] and [24].

In addition to attitude factors, school environment factors also helped B40 students to read and write. However, Malay Language teachers told that B40 students' attitude led them to still be incompetent in reading and writing. The school offered multiple efforts in creating a conducive environment to read and write in school, but the B40 students of Malays, Chinese and Indians still cannot read and write well. Some of the schools' efforts in creating a language environment in schools were organising various programs for the Malay Language in school, providing facilities to ensure that learning the Malay Language as in reading and writing activities can be carried out. The study by [17] confirmed that environmental factors also affected poor and rural students' learning.

According to [7], environmental factors affected the learning and achievement of needy students. In this study, researchers found that parents of B40 students, regardless of the Malays, Chinese, and Indians, could not provide a Malay Language learning environment for their children. Apart from financial and economic constraints, these B40 students' parents had no awareness of the importance of their children's education. That was why many parents of B40 students interviewed stated that they expected the 
school to educate their children to read and write the Malay Language.

As leaders, Malay Language teachers continuously help with reading and writing problems faced by the students of B40. Malay Language teachers need to be confident that they can help students B40 is read and write well, such as teaching the Malay Language to non-standard, that is, mixing the Malay Language with Malay colloquial standard. However, the study discovered that the Malay Language teachers did not feel confident to help B40 students master reading and writing skills. It is because their reading and writing proficiency was minimal and limited (very weak and weak).

For the B40 Chinese and Indians students, the teachers believed it was difficult to help because the basic Malay Language in primary schools is very poor. Most of them studied at Chinese and Tamil National Type Schools. The situation worsens when entering a high school where they cannot read and write well. A study conducted by [20] found that Chinese students were very weak in writing skills. Writing is influenced by their mother tongue, which is Mandarin. It is the reason they fail to produce good essay writing.

To overcome the reading issue, the study determined that Malay Language teachers used various strategies, approaches, methods and techniques to help B40 students learn the Malay Language. These Chinese and Indians mastered reading and writing skills. Studies conducted by [2] suggested ICT and interactive multimedia as a method that can help students master reading skills. [1] recommended KWLH techniques used by the Malay Language teachers to help students master reading. As for writing skills, the study by [10] proposed methods of teaching writing skills from easy to difficult.

[26] recommended project-based learning methods to help students weak in writing skills. [21], [23] and [30] suggested that Malay Language teachers apply higher-order thinking skills in teaching and learning. While [5] proposed a method of student-centred learning in teaching the Malay Language. In other words, there are a variety of ways, approaches, techniques and strategies for teaching and learning the Malay Language [28] that teachers can use to teach students who are learning the Malay Language as a first language, second language or foreign language. Teachers can use many interactive applications such as flipped classroom, virtual learning classroom (VLE Frog), google classroom, google meets and cahoot to help students who are weak and incapable of reading and writing to learn the Malay Language.

Besides, this study also discovered that various forms of incentives used by the Malay Language teachers to ensure B40 Malays, Chinese and Indians students could read and write well, such as the following:

1. Encourage B40 students to participate in reading and writing activities.
2. Ensure that the work of B40 students can be produced quickly.

3. Provide reading and writing activities that are appropriate to the level of mastery and cognitive of B40 students.

4. Give rewards and appreciation to B40 students through the work that students do.

5. Use various methods, approaches, techniques, and strategies to help B40 students master reading and writing skills.

6. Talk to class teachers and other subject teachers about B40 students who have difficulty reading and writing.

7. Inform the parents of B40 students about their child's attitude and educational performance.

Various incentives proposed by the Malay Language teachers are relevant [28], [29] maintained that the teacher is the key to students' success in mastering the Malay language. Among the main findings by [24] is an engaging, practical and fun teacher teaching method that helps students master reading skills. [26] stipulated that Malay Language teachers use project-centred learning methods to help students master writing skills. The teacher factor also affected the level of reading and writing proficiency among the B40 students considered.

Thus, from Malay Language teachers' perspective, reading and writing problems among B40 Malays, Chinese and Indians students should be addressed immediately. B40 students' teachings require persistence and attentiveness by the Malay Language teachers. Parents also need to collaborate with the Malay Language teachers and schools to help their children master reading and writing skills well and useful.

\section{Conclusions}

Ergo, reading skills are imperative skills that students need to master before mastering writing skills. Students who do not master reading skills will have difficulty understanding what is read. Hence, students will fail to write well. Some of them do not know what to read and write.

Writing skills are various language skills to construct based on specific rules. Therefore, students should be proficient in these skills because it involves many daily activities in life. On the other hand, teachers play a significant role in ensuring that students can master these skills.

Students from the B40 families are often of low-income earners, living in rural or suburban areas, with many siblings, having uneducated parents, working labour, and living in small houses or cheap houses [19].

In conclusion, reading and writing skills are two language skills that are still arduous for B40 family students to master. Therefore, this study identified and validated the hypothesis by conducting interviews with 
teachers, students and parents on reading and writing problems.

\section{Acknowledgement}

Thanks to the Faculty of Education, UKM, for providing the Education Faculty Research Fund with research code: GG-2020-083 till this article is successfully published.

\section{REFERENCES}

[1] J. Abdul Rasid and B, Nurfatin Nabihah, "Kesan Penggunaan Teknik KWLH dalam Kemahiran Membaca Murid Sekolah Jenis Kebangsaan Cina.” Jurnal Pendidikan Bahasa Melayu (Malay Language Education Journal), Vol. 8, No. 2, pp 48-56, 2018.

[2] J, Abdul Rasid and A.Z. Zulkafli, "Keupayaan Kemahiran Membaca dan Menulis Bahasa Melayu Murid Sekolah Rendah Kebangsaan Luar Bandar," Konvensyen Pendidikan Nasional 2008. Organised by Universiti Pendidikan Sultan Idris, 2 - 4 June 2008

[3] J. Abdul Rasid, H. Norhashimah and O. Shamsudin, "Multimedia Interaktif Mempertingkatkan Pembelajaran Kemahiran Membaca Murid-Murid PROBIM," Jurnal Pendidikan Bahasa Melayu, (Malay Language Education Journal), Vol. 2, No. 2, pp 46-53, 2012.

[4] J. Abdul Rasid Jamian, "Permasalahan Kemahiran Membaca dan Menulis Bahasa Melayu Murid-Murid Sekolah Rendah di Luar Bandar,” Jurnal Pendidikan Bahasa Melayu, (Malay Language Education Journal), Vol. 1, No. 1, pp 1-12, 2011.

[5] L. Alizah and M. Zamri, "Students Learning Centered". Bangi: Universiti Kebangsaan Malaysia Press, 2018

[6] D. Ary, L.C. Jacobs, C. Sorenson and A. Razavieh, A. "Introduction to Research in Education", Belmont: Wadsworth, 2006

[7] C. Buarque, M. Spolar and T. Zhang, "Education and poverty reduction", Review of Education, Vol. 52, pp 219-229, 2006.

[8] L. Celinea and M. Zamri, "Reciprocal Practice Reading among Bidayuh Etnics Pupils". Bangi, Malaysia: Universiti Kebangsaan Malaysia Press, 2018.

[9] L. Celinea, "Amalan Pembelajaran Reciprocal (Timbal Balik) dalam Kemahiran Membaca Bahasa Melayu dalam Kalangan Murid Peribumi Bidayuh". Tesis Doktor Falsafah, Fakulti Pendidikan, Universiti Kebangsaan Malaysia, 2018.

[10] C.H. Che Zanariah and A.R. Fadzilah, "Pelaksanaan Pengajaran dan Pembelajaran Kemahiran Menulis di Sekolah Rendah", Jurnal Pendidikan Bahasa Melayu, (Malay Language Education Journal), Vol. 1, No. 1, pp 67-87, 2011

[11] F.P. Chew, "Masalah Pembelajaran Bahasa Melayu dalam Kalangan Murid Cina Sekolah Rendah", Jurnal Pendidikan Bahasa Melayu, (Malay Language Education Journal), Vol. 6, No. 2, pp 10-22, 2016.
[12] J.W. Creswell, "Educational Research: Planning, Conducting and Evaluating Quantitative and Qualitative Research", $2^{\text {nd }}$ Edition. New Jersey: Pearson Education, 2008.

[13] Departmen of Statistics, "Pendapatan Garis Kemiskinan". Putrajaya, Malaysia: Prime Minister Department, Malaysian Goverment, 2017.

[14] Kementerian Pendidikan Malaysia, "Pelan Pembangunan Pendidikan Malaysia 2013-2025”. Putrajaya, Malaysia: Bahagian Pembangunan Kurikulum, 2013.

[15] Kementerian Pendidikan Malaysia, "Kajian Murid Lemah Pencapaian Akademik". Putrajaya, Malaysia: Bahagian Perancangan dan Penyelidikan Dasar Pendidikan, 2016.

[16] C. Marshall and G.B. Rosmann, "Designing Qualitative Research", $4^{\text {th }}$ Edition. Thousand Oaks, CA: SAGE Publications, 2006

[17] S. Mohamad Johdi, K. Masliza, L.L. Loven, J.F Henry and R. Moini, Rubin, "Kajian terhadap Faktor-Faktor Yang Mempengaruhi Pencapaian Pelajar dalam Penilaian Menengah Rendah di Sabah". International Conference on Educational Research, 5-7 Julai, Labuan, Malaysia, 2012.

[18] A.R. Mohd Fuad, "Aplikasi, Sikap dan Masalah Guru dan Murid di SJK Tamil terhadap Pembelajaran dan Pemudacaraan Bahasa Melayu Berkonsepkan Flipped Classroom", Kertas Projek Sarjana Pendidikan, Fakulti Pendidikan, Universiti Kebangsaan Malaysia, 2018.

[19] A.R. Mohd Nazri, "Pembangunan Model Home Schooling Berasaskan Nilai dan Amalan Masyarakat Bagi Kanak-Kanak Orang Asli”, Tesis Doktor Falsafah, Fakulti Pendidikan, Universiti Malaya, 2014.

[20] A.R. Noor Hidayu and O. Yahya, "Keberkesanan Peta Bulatan dan Peta Alir dalam Meningkatkan Penguasaan Kemahiran Menulis Karangan Naratif Murid-Murid Cina”, Jurnal Pendidikan Bahasa Melayu, (Malay Language Education Journal), Vol. 6, No. 2, pp 68-77, 2016.

[21] M.Y. Nor Azimah and M. Zamri, "Keberkesanan Pendekatan Didik Hibur terhadap Pencapaian Kemahiran Membaca Bahasa Melayu dalam Kalangan Murid Lemah", Prosiding Seminar Pascasiswazah Pendidikan Bahasa Melayu dan Kesusasteraan Melayu Kali Ke-3, 381-390. Bangi: Fakulti Pendidikan Press, Universiti Kebangsaan Malaysia, 2014.

[22] A.R. Nor Hamizah, "Faktor Demografi dan Sosioekonomi Kumpulan B40 dalam Pemilikan Takaful Keluarga/Insuran Hayat", 2nd International Conference on Economics and Banking 2016 (2ndICEB) at 24-25 May, Kuala Lumpur, 2016.

[23] R. Saemah and M. Zamri Mahamod, "Creativity in Teaching and Learning" (Eds.).Bangi, Malaysia: Universiti Kebangsaan Malaysia Press, 2016.

[24] T. Tamam, M. Zamri and H. Afendi, "Faktor dan Kesan Masalah Membaca dalam Kalangan Murid Sekolah Rendah Kerajaan di Brunei Darussalam”, Jurnal Pendidikan Bahasa Melayu, Vol. 1, No. 1, pp 89-107, 2011.

[25] N. Usang, "Implikasi Kepimpinan Pengajaran Pengetua, Kepuasan Kerja dan Pengajaran Berkesan Guru terhadap Prestasi Peperiksaan Pelajar Sekolah Menengah Luar 
Bandar di Sarawak", Tesis Doktor Falsafah, Universiti Malaysia Sabah, 2012.

[26] O. Yahya and P.O. Dk. Suzanawaty, "Keupayaan Menguasai Kemahiran Menulis Pembelajaran Berasaskan Projek Nilam dalam Penulisan Berbentuk Risalah di Sekolah Rendah", Jurnal Pendidikan Bahasa Melayu, (Malay Language Education Journal), Vol. 4, No. 1, pp 19-29, 2014.

[27] R.K. Yin, "Applications of Case Study Research", 3th Edition. Thousand Oaks, CA: SAGE Publication, 2012.

[28] M, Zamri, "Innovation T\&L in Malay Language Education", 1st Edition. Tanjung Malim, Malaysia: Universiti Pendidikan Sultan Idris Press, 2014.

[29] M. Zamri, "Learning Strategies: Inventory How to Learn Malay Language", 1st Edition. Kuala Lumpur, Malaysia: Dewan Bahasa and Pustaka Press, 2015).

[30] M, Zamri, "Mind Map: Teacher Creativity Stimulates
Learning Thinking”, (Eds.). Bangi, Malaysia: Universiti Kebangsaan Malaysia Press, 2020.

[31] M, Zamri, "Sociolinguistics and Language Teaching", 4th Edition. Bangi: Faculty of Education Press, Universiti Kebangsaan Malaysia, 2020.

[32] M. Zamri and A.R. Anita, "Equality of Access Education". Bangi, Malaysia: Universiti Kebangsaan Malaysia Press, 2020.

[33] A, Zarinah, P. Farah Syuhada and I. Zanariah, "B40 Family: Stress aand Strenth", Journal of Advanced Research in Social anda Behavioural Sciences, Vol. 10, No. 1, pp 91-102, 2018.

[34] Departmen of Statistics, Prime Minister Department, Malaysian Goverment, "Golongan Isi Rumah B40, M40 dan T20 di Malaysia berdasarkan Pendapatan", dlm. CompareHero.my, September 24, 2020. https://www.comp arehero.my/budgets-tax/articles/klasifikasi-pendapatan-dimalaysia-t20-m40-dan-b40 (11 February 2021) 